\title{
Protein Spinster Homolog 2
}

National Cancer Institute

\section{Source}

National Cancer Institute. Protein Spinster Homolog 2. NCI Thesaurus. Code C132176.

Protein spinster homolog 2 (549 aa, $\sim 58 \mathrm{kDa}$ ) is encoded by the human SPNS2 gene.

This protein plays a role in the transport of sphingosine 1-phosphate (S1P). 